\title{
A BEHAVIORAL THEORY OF THE FIRM: SPECIFICS OF CZECH ENTREPRENEURIAL BEHAVIOR
}

\author{
Ivana Mandysová
}

\section{Introduction}

Despite voluminous literature on the entrepreneurial behavior, studies examining Czech specifics are very rare - specified below. Most of studies come from US and relatively few from Europe, namely Netherlands and Austria. The purpose of this study was to extend this line of research by applying Behavioral Theory of the Firm as a theory of human choice and decisionmaking in firms by incorporating the practices of Czech entrepreneurial specifics. Author observes on the decision-making process with commentaries examining new Czech facets of firm behavior. Analysis allowed examination of the effects of behavioral characteristics in the context. This approach further contrasts with the approach of most prior studies, which examined the entrepreneur in isolation.

Now it has been nearly 28 years since the socialist regime fell and the Czech Republic moved to a free market system. The transition process included restitution and the return of confiscated property and required not only changes to the economic system, but also changes in personal attitudes and behaviors toward private business. At the time, bankrupt socialist firms served as a source for customer portfolios, technical skills, ideas, and educated experts; many firms have been founded on these bases. The transformation included social, political, and economic change. This goes hand in hand with individual behavior and transformation of values and attitudes. Entrepreneurs renewed their family traditions, carrying on their fathers' and grand-fathers' heritage, which had been interrupted for 40 years. With difficulty, they rediscovered original production technologies, and buildings to be restituted were in ruins. These successors invested their time and private savings in order to achieve the life attitudes of their ancestors. Although they lacked technical skills, know-how, business experience, and capital; a pride and reverence for their ancestors were determining factors in their businesses.

This study focused on entrepreneurial behavior and considered an entrepreneur and its decision making. Currently much discussion pivots around the ideas of entrepreneurs' competencies and capabilities, and the concept of the learning organization or knowledge-creating company. Article analyses entrepreneurial routines, decisions, and behavioral practices within the firm and argues that they are critical to the ability of a firm to function. Investigating the model behavior of firms, the new ideas featured in this article update a book of Cyert and March that has become a worldwide known.

\section{Review of Scientific Literature}

A major problem in the field of economics and behavioral sciences is how to create a relevant theoretical basis. Theories should be built as an aggregated version of microeconomic case studies observations, while nothing than aggregation in the theoretical sense may not be possible (Lucas, 1987). To this end, there was an urgent need to obtain detailed knowledge of the nature of a researched phenomenon.

The amount of literature and studies focused on entrepreneurial behavior is huge and rapidly growing. Different empirical studies are based on decision and strategy making, behavior and environment (Yasai-Ardekani, 1989), and many other interactions and relations.

The theoretical background here addresses the existing theories of organizations in order to identify any limitations in current theories. It also justifies our motive for further developing the behavioral theory of the firm in terms of Czech specifics.

The manner in which the entrepreneurs decide has important implications for company, 
processes and performance. Entrepreneurial behavior has been characterized as a strategic response to problems or challenges (Vaessen \& Weaver, 1993).

This article utilizes the context of 'The Behavioral Theory of the Firm' by Cyert and March (1963), which has been extremely influential. In the 1960s, the so-called 'behavioral school of economic theory' attempted to fill a gap in economic theories. The new approach focused on economic choices and personal motives in manager behavior. Its foundational concepts, assumptions, and aspiration have influenced behaviorally oriented theorists in the sphere of management, strategy, and organization.

It is difficult to obtain a consensus among researchers and writers as to who is an entrepreneur. This article considers entrepreneurs being equal to owners and managers of the firm. According to Kao (2013) an entrepreneur is a person who organizes and manages a business. Though these are narrowly focused, the literature nevertheless supports the view that there is a wide range of different interpretations. While economists consider the entrepreneur as a factor of production, some theorists stress that entrepreneurs are risk takers.

The classic school of economic theory is based on a dynamic, change-oriented, and innovative attitude. Schumpeter (1934) identifies the role of innovation and argues that the key to the success of markets lies in the "spirit" of the entrepreneur who persists in developing innovative products and technologies, and keeps reducing costs. Animal spirits is gotten from the Latin term "spiritus animalis" which means the breath that awakens the human mind. Animal spirits may also refer to entrepreneurship, to the risk involved in taking investment decisions which invariably have an element of risk attached. Animal Spirits is a term used by John Maynard Keynes to explain why decisions are made even under conditions of uncertainty. In Keynes' 1936 publication, The General Theory of Employment, Interest and Money, the term "animal spirits" is used to describe human emotion that drives business and entrepreneurship. "Most, probably, of our decisions to do something positive, the full consequences of which will be drawn out over many days to come, can only be taken as the result of animal spirits - a spontaneous urge to action rather than inaction, and not as the outcome of a weighted average of quantitative benefits multiplied by quantitative probabilities." (Keynes, 1936). In modern economic terms, animal spirits describe the psychological factors that drive entrepreneurs to take action.

Management and organizational theories perceptions have been gradually redirected from quantitative to qualitative characteristics. These theorists' latter works generally involve greater emphasis on the manager's own abilities, trust in human potential, and managerial strategies that respect nature and humanity. According to Field (2007), the transition from the former to the latter perception also requires new ways of assessing management theories, focusing more deeply on the individual personality.

As society becomes increasingly complex and comprehensive, this focus has developed further. It explores the opportunity costs that managers face as they dedicate more and more effort to get information, to innovate, to be competitive, and to establish and maintain contacts. Economists who are close to sociology challenge the assumption of rational behavior (Williamson, 1963) of individuals and firms. They point out that manager information is incomplete or insufficient. This is evidenced by the work of theorists based on behavioral approaches. Behavioral approaches respect the influence of an environment under risk and uncertainty. Preferences of managers influence the process of decision-making. Kirzner (1997) argues that the business decision-making process is vital to the effectiveness of economy.

Yet, even in later views, (McDermott \& Taylor, 1982) environmental factors predominate over abilities and actions of managers. In reality, companies are rarely able to use optimized calculations; these are often replaced by simple procedures, routines, experience, or imitation. These methods are summarized in the concept of heuristics. The heuristic approach consciously chooses not the optimal solution but the acceptable one (Bingham \& Haleblian, 2012). Applying the heuristic approach may be useful, in particular, in cases where the optimization calculation requires a high cost of information, time, and resources; it is thus compensation for deviation from the optimum. Behavioral theory deals with the effects of social, cognitive, psychological, and emotional factors on the economic decisions and actions of individuals like managers or 
entrepreneurs. Risk tolerance is a crucial factor in entrepreneurial decision making. It is defined as entrepreneurs' willingness to engage in a business activity whose outcome is uncertain. Behavioral theory is primarily concerned with the bounds of rationality of economic agents (Kameda \& Diasuke, 2002).

Pred (1967) improved existing location theory by incorporating the phenomenon of 'imperfect behavior', 'incomplete knowledge,' and other psychological variables. Pred does not deviate from the classical theory. His behavioral critique of the classical theory of localization is actually very clear. His views are based on the idea of the satisfactory behavior of imperfectly informed managers who make decisions. After all, the lack of information creates uncertainty among managers. Moreover, uncertainty leads to 'safe' choices and decisions. This means that company owners and managers tend to imitate each other and their behavior is dominated by the 'herd instinct.'

Cyert and March created a general theory of economic decision making of business firms. Their theory is empirically relevant and processoriented, and it observes procedures by which businesses and managers make decisions: Namely, a firm's decision is the execution of its choice; it is made in terms of objectives from among a set of alternatives on the basis of available information. According to Cyert and March (1963), there is disagreement about the theory of the firm in three respects.

Behavioral Theory of the Firm is a classic work by Cyert and March. It significantly contributes to improving contemporary firm theories in the field of organizational management and behavior for its broad scope and depth of information. It has become a classic business book and remains relevant to this day. The article provides new material which puts the original work in a contemporary context.

The first is about what the theory is; the second is about the extent to which the theory is defective; and, the third is about the appropriate methods for improving the theory. The first of these disagreements makes it difficult to describe any current consensus on the theory of the firm. Authors state that, in fact, there is no consensus and they reduce theories to two assumptions of rationality: firms seek to maximize profits; and, firms operate with perfect knowledge. The attack on the assumption of profit maximization does not deny the importance of profits but rather argues that profit maximizing should be replaced by the goal of making satisfactory profits.

Satisfactory profit (Simon, 1947) represents a level of aspiration that the firm uses to evaluate alternative strategies. According to Simon (1957), the level of satisfactory profits may change over time, but, in the short run, it defines only two values - good enough and not good enough. In terms of the assumption of perfect knowledge, Simon states that information is not given to the firm but rather it must be obtained from the external environment. The order in which the environment is searched determines to a substantial extent the decisions that will be made (Child, 1972).

New approach to economic theory by Kahneman (2003) sets the founding text in behavioral economics. Thaler (2017) argues that decision makers do not make rational economic decisions. Bias and flaws influence economic actions described as "planning self and doing self" (Thaler, 2017).

Cyert and March (1963) established a set of foundational concepts at the cognitive level as well as a set of major relational concepts serving as theoretical mechanisms. Contemporary management and organizational theories differ in conceptualizing firm behavior, understanding differences, defining the main actors, and in framing implications for practice.

The theoretical review looked at both original ideas and new developments in this field in terms of entrepreneurial behavior. The behavioral approach compensates for the lack of attention, which is the classical economic theory devoted to internal aspects of companies.

The new approaches focus on economic choices, personal motives, and the behavior of entrepreneurs, which create structures that ultimately anchor entrepreneurial thinking. They emphasize the role and quality of the human factor, and the individual's communication skills, decision-making, and innovative thinking (Krueger, 2007).

In summary, there is no unique generally accepted theory, but certain signs allow us to assume that in this area there is a rising new paradigm. The new paradigm emphasizes fundamental significance of animal spirits (Keynes, 1936) and is likely to be at the intersection of managerial, organizational, and behavioral theories. 


\section{Research Methodology and Sample}

This article is based on an objective, qualitative, comparative, and long-term research case study of 54 firms. Theorists as Cyert and March (1963), and Simon (1947; 1957), unlike neoclassicals, proceed inductively. Behaviorists do not examine how companies should behave, but rather how they really do behave. Conclusions are derived from the generalization of empirical observations. Behaviorists describe the behavior of firms and then correlate these to explanatory factors. Hence, this is the method of presented study. Because of huge amount of empirical studies focused on entrepreneurial behavior, decision and environment, it was decided to set research question in an open and explorative manner. "What are the specifics of Czech entrepreneurial behavior in terms of A Behavioral Theory of the Firm by Cyert and March?"

To that end we chose a qualitative research method, which involves the collection and analysis of qualitative data. This article does not assess institutional reforms or the degree of success of the transitional process, but it focuses on exploring and explaining the way managers make economic decisions in Czech. The firm, its importance, and legitimacy are analyzed as the unit for the detailed empirical study and theoretical analysis. Appropriately, the research integrates social and human factors, including values such as confidence, prestige, a feeling of home, insecurity, fear. Identifying the actual behavior and daily work it creates a description of a firm's decision in terms of a specific series of semi-decisions used to reach a choice. It discovers inner mechanisms as well as their genesis and incorporates them into the classical behavioral theory of the firm.

Results gained through an analysis of quantitative indicators could be of some use in statistical research, but they would not demonstrate the real reactions of entrepreneurs nor their motives. To verify and critically examine theoretical models article applies statistically established patterns of association between model and context variables used by YasaiArdekani (1989) and mathematical measuring analysis (Kutner et al., 2005; Soofi et al., 2000). These offer an interpretation of entrepreneurial behavior as a product of primarily adaptive/ manipulative models which contextual variables are assumed to impose. The behaviour and the decision making are compared and conclusions are drawn. This multiplier approach enables us to achieve a more accurate result.

Qualitative research proceeds inductively and statements are generated only during the research as part of trying to understand a new problem. The reason for choosing the qualitative method here is that this issue is quite complex. The main benefit of the method is to provide in-depth insight into 54 enterprises. This requires an explorative approach. This type of research method allows for debate about the results, provided that the conditions of the research remain universally certain with explicitly recognized standards. Soofi et al. (2000) defines qualitative data as "...detailed, concrete descriptions of people and events, drawn from direct observation, interviews, case studies... Hendl (2005) defines that qualitative research is the process of searching for the essence of the topic based on different methodological traditions. Researchers create a complex, holistic picture, analyzing different types of data, and thereby learn about the views of the respondents.

\subsection{Data Collection and Processing}

The investigated 54 firms come from the Pardubice region. The numbers of SMEs in the Czech Republic and in the Pardubice region (2016) were identified and SMEs were divided by sector. In order to get a statistically representative sample, we assured that the ratio of the investigated companies in the sample and those in the NACE structure correspond (see Tab. 1). The research was carried out over the past five years, mapping 28 years of history of the individual firms. The procedure of empirical data collection was as follows: data were obtained by interviews with entrepreneurs, managers, or owners of businesses. Interviewed entrepreneurs are a versatile group of people, all with valuable and comprehensive insights of their firm' genesis, development and daily problems. There was an inherent difficulty in finding entrepreneurs that were willing to participate in our study which in the end limited our sample to 54 entrepreneurs.

Respondents were recorded and then the text was literally transcribed. There were informal semi-structured dialogs as part of the process. Questions had a sequence and wording that were not worked out beforehand. The framework of the interview was established, 
and questions were tailored to crystallize the situations inside and outside of the firm that evoked a need for a decision and subsequent choice of action. Their dynamics and causal mechanisms were emphasized.

The interviews searched for links and moments that particularly affected the entrepreneurial behavior towards five business environment components: Location, Suppliers, Human resources, Customers and competition, Finance and legislation. The questions were aimed at identifying the initial idea of starting the entrepreneurship (where, when, why), how the respondent developed gradually as an entrepreneur, and descriptions of the dynamic development of the firm activities to the present. For example, the following questions were posed: What kind of decisions do entrepreneurs make? How do these manifest? How is the external or internal situation perceived by the entrepreneur, and what is his response?

Three-hundred pages of text were obtained. Collected and corrected text was organized and integrated properly by prevailing assumptions and their meaning taking into account theoretical patterns. Case study data were analyzed. Parts of the assembled information were selected and simplified to enable our analysis and its evaluation. We combined the data into relating categories in order to identify links and lastly use the processed material to build theory.

In the analysis we have applied the theories we found relevant to fulfil our aim. Data were connected to these theories finding a match or mismatch to be in accordance with main ones, especially Cyert and March Behavioral theory of the firm, striving to include Czech specifics. Accordingly, we distinguished outcomes under the different behavioral models adaptive/ manipulative (Vaessen \& Wever, 1993; Dobbs \& Hamilton, 2007).

\subsection{Empirical Findings}

Examples of assembled case study text demonstrating actions and decisions:

\section{Firm and location}

'I started the business in a garage remodeled as a workshop.' 'I restituted a service garage of agricultural machinery owned by a state

\section{Tab. 1: Number of sample firms in relation to NACE}

\begin{tabular}{c|l|r|r|r} 
Code & \multicolumn{1}{|c|}{ CZ-NACE classification } & \multicolumn{1}{c|}{$\begin{array}{c}\text { SME number } \\
\text { in region }\end{array}$} & \multicolumn{1}{c}{ In $\%$} & \multicolumn{1}{c}{$\begin{array}{c}\text { Study sample } \\
\text { number }\end{array}$} \\
\hline A & Agriculture, forestry and fishing & 4.64 & $4.07 \%$ & 2 \\
\hline B & Mining and quarrying & 1.15 & $1.01 \%$ & 1 \\
\hline C & Manufacturing & 34.06 & $29.88 \%$ & 14 \\
\hline D & Electricity, gas, steam and air conditioning & 0.96 & $0.84 \%$ & 1 \\
\hline supply & Water supply; sewerage; waste & 0.79 & $0.69 \%$ & 1 \\
\hline F & lonstruction & 19.93 & $17.48 \%$ & 15 \\
\hline G & Wholesale and retail trade; repair of motor & 31.1 & $27.28 \%$ & 1 \\
\hline Q & Health and social work activities & 1.28 & $1.12 \%$ & 1 \\
\hline R & Arts, entertainment and recreation & 1.08 & $0.95 \%$ & 7 \\
\hline S & Other services activities & 15.03 & $13.18 \%$ & 1 \\
\hline T & Activities of households as employers & 1.82 & $1.60 \%$ & 1 \\
\hline U & Activities of extraterritorial organizations & 2.17 & $1.90 \%$ & 54 \\
\hline Total & & 114 & $100.00 \%$ & \\
\hline
\end{tabular}


farm.' 'I initiated the business as my original employment in a state company did not satisfy my ambitions.' 'We had an idea and we needed to verify such a function in real market conditions so we went to Germany and Belgium to watch similar firms.' 'Establishing the firm was an enormous risk as we would be first with this technology on the Czech market.' 'We had no experience, so we bought the production line and disassembled it into pieces in order to see how it worked.' 'The restitution process of the premises was prolonged so we moved our employees into a military tent equipped with a hot air heating unit.' 'By chance, we learned about free spaces of the former state-owned mail-order business.'

\section{Suppliers}

'We revise and change our suppliers on an everyday basis because of bad quality and delivery delays.' 'In the business environment, we face handicaps that increase our additional costs.' 'We were afraid to be dependent on only one supplier.' 'There were many negative experiences with construction firms that regularly did not comply with the contracts delivering low quality, delays or insolvency; lawyers of construction companies are experienced and we suffered the consequences and had to quit cooperating.' 'We tried to buy cheaper components in China, but the quality of was bad.' 'We use Czech made material only as we use only good quality ingredients.' 'Dealers keep contacting us, but they cannot be trusted because of bad quality.' 'We keep comparing quality and price as the market is enormously unstable.'

\section{Human resources}

'We have recruited/poached new colleagues from my previous job in the state owned company.' 'I established the firm together with seasoned managers that had already known the tricks of entrepreneurship under the old regime based on special permission.' 'We stopped recruiting via the labor office as only lazy people came.' 'The company faces the problem of a lack of a machinist because this craft slowly disappeared from our region.' 'The main reason is that there is no educational institution for this craft in the region. 'We signed an agreement with a training center in the next region in the end.' 'The biggest obstacle for employees was the hygiene regulations that are valid in the food industry.'

\section{Customers and competition}

'We were the only firm using this unique technology on the Czech market.' 'We succeeded to get a bio-certificate in order to improve competitiveness of our food products.' 'We reached our potential customers via direct mail as advertising in local magazines had no effect.' 'We could penetrate supermarkets with our bakery production, but we had to distribute it to all supermarket branches in the region, which raised the transportation costs.' 'We have lack of knowledge to penetrate the international market.' 'Business relationships and trust are more important than regional proximity.' 'We simply imitate our competitors' behavior instead of paying for expert analysis.'

\section{Financial Market, state legislation}

'Local finance and loan accessibility is limited. The capital market is integrated into supranational financial system and local branches are not aware of the local financial and loan situation.' 'Our liabilities were too high so we postponed payments to our suppliers, and we postponed salary payments, and we received a loan from a bank in the end.' 'The administrative burden was high so we moved the seat of the firm to Prague as the new address is more prestigious and out of the reach of financial authorities' inspection.'

\section{Measurements and Statistical Methods}

For some variables it is difficult to express them numerically, so we determined a scale of score according to analysis of the qualitative sources of Neter et al. (1985) and applied regression method (Rao, 1973).

In reviewing the literature, we found a categorization of entrepreneurial strategies and we bring to light two perspectives which may be linked to each other. Classics like Child (1972) developed the model of entrepreneurial behavior significantly determined by several factors like the personal characteristics, scaling from adaptive to manipulative. Entrepreneur performs ability to adapt to the conditions under imperfect information, to manipulate and form a pressure in response as the contra-reaction to eliminate negative impacts (Cyert \& March, 2013). Reactions of the entrepreneurs are rational however they could be limited by the bounded rationality or business conditions (Chandler et al., 2009). Entrepreneurs 
counteract the constraints by making economic decisions that are not made according to designed strategic plans. They manipulate the shortcomings and disadvantages of business environment. They exploit chances in spite of additional expenditures that increase the costs (Kameda \& Diasuke, 2002). Chakravarthy (1982) developed a behavioral model which conceives type of behavior and ranges from passive to active, from adaptive to manipulative one. The type of entrepreneurial behavior differs under the conditions of firm size, firm location, human resources availability, perceived finance availability, supplier's availability, and customers' availability. The dichotomy exploited in this study may suggest entrepreneurial behavior divided. Yet several decisions or behavioral patterns contain seeds of convergence of both perspectives.

It is argued that available model in fact attempts to explain entrepreneurial behavior, whereby entrepreneurs and managers decide upon courses of decision making and problems solving. These actions typically include not only the adaptation to constraints but also the manipulation of features and the choice of relevant solution.

\section{Variables}

Entrepreneur's own perceptions play a key role in the business. As Bierly and Daly (2007) argued, firms come to make decisions via their perceptions. Similarly, Field (2007) suggested that firms respond to what they perceive and that unnoticed events do not affect firm' decisions and actions. Consequently, entrepreneur's own perceptions lie at the heart of behavioral model choice. Therefore perception is used to state variables (Witt, 2007; Field, 2007).

As the representational variables for entrepreneurial behavior were chosen manipulative or adaptive behavioral patterns (Child, 1973; Vaessen \& Wever, 1993).

Four attributes of entrepreneurial behavior were measured. Measurements were developed by Child (1973) using abbreviated scale developed by Soofi et al. (2000), adopting the same scoring procedure they used.

Change of suppliers appears when a firm seeks to replace supplier of a component in order to become less vulnerable to its whims. Reliability, stability and quality in supplies and payments can be achieved by changing a supplier. This kind of pro-active entrepreneurial behavior protects from production disruption, poor quality products and image degradation. The rate of change of suppliers is a number of changes detected in last 15 years for each firm separately divided into scale 1 (0-10), 2 (11-30), $3(31+)$.

The rate of change of customers is a number of changes of customers for each firm followed up for 15 years back divided into the scale 1 (0-10), 2 (11-30) and 3 (31+). Information about the customers was part of the research as well as information about the suppliers which serve as a background for the both behavior variable. Variable model shows the Manipulative or Adaptive entrepreneurial behavior in context to different types of context variables (size, supplier's availability, employees availability).

Human resource practices variable displays flexible human resource practice. For every firm is determined value 0 or 1 . Value 1 means that firm pro-actively searches for qualified employees even on supra-regional level, redundant workers are laid off; while on the other hand value 0 is for facing labor and skills shortages causing serious consequences for business.

Variable Location practices represent the factor of the location choice as it is perceived by the entrepreneurs themselves (Dobbs \& Hamilton, 2007). Location behavior gives a firm considerable advantage of local conditions. Pro-active behavior of a firm in disadvantageous location does not prevent firm from being successful (Pred, 1974). Firm can assure its external inputs and deliveries in local conditions, which differ with respect to type of resources. Qualitative data related to this topic were analyzed and for each firm there was set value 0 for disadvantageous location with no flexibility or value 1 for advantageous location reached by pro-active behavior.

The article updates classical theory by Czech context. Context variable is a variable that is constant but varies by contextual specifics. It is not controllable by the firm but affects its performance, its strategy, behavior, and its decision process. In our terms, examples are economic, demographic, social, and include specific Czech social-cultural context like stability, lifestyles, social values, personal motives and own culture variables. Political-legal context includes specifics of political stability, economic policies, labor legislation, legal framework, and tax system and incentives policy. 
Size of firm is defined as a logarithm of the number of the employees (Yasai-Ardekani, 1989) for each of the 54 firms. Range of number of employees ranges from 1 for micro firm to 206 for medium firm.

Suppliers' availability is a dummy variable and shows availability of convenient suppliers. Value 0 means a good availability. Value 1 means the firm the lacks suitable suppliers (Yasai-Ardekani, 1989).

Context variable Finance availability represent rate of limited availability of the finance sources. It is measured from the entrepreneur perception, who indicates the circumstances and the rate of availability of the various finance resources. For better interpretation of the results of the analysis, this variable is as well expressed with dummy variable 0 and 1 . Value 0 means that availability of finance is not limited and the level of available finance resources is satisfying while value 1 states that the availability of finance resources is limited. (Yasai-Ardekani, 1989).

\section{Results}

Method used regress each model variable on the context variable. All context variables were included in each regression equation so that the effects of each on model could be examined in the presence of others. In each equation, the coefficients of the context variables measured the effects of context on model under behavioral conditions, and the coefficients of the crossproduct terms gave the difference between the effects of context on model under the two conditions of model behavior $(0=$ adaptive, 1 = manipulative). Thus, using Kutner's methodology (Kutner et al., 2005) computed are the effects of context on model under conditions of adaptation/manipulation as the sum of the coefficients of the context and the respective cross-product terms in the regression equation. Tested is significance of the effects (Kmenta, 1986).

Tab. 2 displays correlation coefficients expressing positive or negative deviation via plus or minus signs of the coefficient. There are also means and standard deviations, which are more important at non-dummy variables, in the system of measuring predominantly with dummy variables or scales with only a few values the meaning is mostly symbolic.

Tab. 3 observes the effects using multiple regression analysis separately under two conditions. In both of groups each behavioral variable (rate change customers, rate of changes suppliers, location practices, and HR practices) was regressed on the context variables (size, suppliers availability, finance availability) under conditions of adaptive or manipulative behavior model (Rao, 1973). Models gained by the regressions analysis were numbered for better clarity. In the last two columns there are $\mathrm{R}^{2}$ and $F$ values expressing significance of the models.

\section{Tab. 2: Correlations coefficients}

\begin{tabular}{l|c|c|c|c|c|c|c|c|c|c} 
& Means & $\begin{array}{c}\text { Standard } \\
\text { Deviations }\end{array}$ & $\mathbf{1}$ & $\mathbf{2}$ & $\mathbf{3}$ & $\mathbf{4}$ & $\mathbf{5}$ & $\mathbf{6}$ & $\mathbf{7}$ & $\mathbf{8}$ \\
\hline $\begin{array}{l}\text { 1. Rate of change } \\
\text { of customers }\end{array}$ & 2.35185 & 0.80464236 & 1 & -0.048490 & $* 0.458753$ & 0.049084 & 0.161031 & -0.089610 & 0.136589 & -0.248650 \\
\hline $\begin{array}{l}\text { 2. Rate of changes } \\
\text { of supppliers }\end{array}$ & 2.14814 & 0.87754820 & -0.048490 & 1 & 0.000832 & 0.149420 & -0.019050 & 0.103703 & 0.154757 & $* 0.358049$ \\
\hline $\begin{array}{l}\text { 3. Size logarithm } \\
\text { 4. Location practices }\end{array}$ & 2.69261 & 1.65184467 & $* 0.458753$ & 0.000832 & 1 & 0.037090 & $* 0.512751$ & $*-0.422525$ & 0.181738 & -0.024870 \\
\hline $\begin{array}{l}\text { 5. Human resource practices } \\
\text { 6. Finance availability } \\
\text { - DUMMY }\end{array}$ & 0.55555 & 0.50156986 & 0.161031 & -0.019050 & $* 0.512751$ & -0.018900 & 1 & $*-0.619686$ & 0.167483 & $* 0.320244$ \\
\hline $\begin{array}{l}\text { 7. Suppliers availability } \\
\text { - DUMMY }\end{array}$ & 0.57407 & 0.49912572 & -0.089610 & 0.103703 & $*-0.422525$ & 0.003165 & $*-0.619686$ & 1 & -0.166900 & -0.104450 \\
\hline $\begin{array}{l}\text { 8. Manipulative_1/ } \\
\text { Adaptive_0 }\end{array}$ & 0.59259 & 0.49596555 & -0.248650 & $* 0.358049$ & -0.024870 & $*-0.404532$ & $* 0.320245$ & -0.104450 & -0.047990 & 1 \\
\hline
\end{tabular}




\begin{tabular}{|c|c|c|c|c|c|c|}
\hline \multirow[t]{2}{*}{ Tab. 3: } & \multicolumn{6}{|c|}{$\begin{array}{l}\text { Multiple regression analysis of behavioral variables on context variables under } \\
\text { different model conditions }\end{array}$} \\
\hline & size log & $\begin{array}{l}\text { Fin. availability } \\
\text { - DUMMY }\end{array}$ & $\begin{array}{l}\text { Supp. availabi- } \\
\text { lity - DUMMY }\end{array}$ & Constant & $\mathbf{R}^{2}$ & $\mathbf{F}$ \\
\hline \multicolumn{7}{|c|}{ Rate change customers } \\
\hline 1. Manipulative & 0.16596361 & 0.238374818 & -0.064142973 & 1.544771330 & 0.1225268 & 0.726107 \\
\hline 2. Adaptive & ${ }^{*} 0.40401884$ & 0.072636163 & 0.141720275 & 1.999459194 & 0.5073451 & 3.295420 \\
\hline Difference & -0.23805522 & 0.165738655 & -0.205863248 & -0.454687864 & & \\
\hline \multicolumn{7}{|c|}{ Rate of changes suppliers } \\
\hline 3. Manipulative & 0.08391441 & -0.326738565 & ${ }^{*} 0.655762284$ & 1.803795590 & 0.6270613 & 8.743312 \\
\hline 4. Adaptive & -0.02428488 & 1.009657976 & 0.666828735 & 1.370769492 & 0.3417637 & 1.661476 \\
\hline Difference & 0.10819929 & *-1.336396541 & -0.011066451 & 0.433026098 & & \\
\hline \multicolumn{7}{|c|}{ Location practices } \\
\hline 5. Manipulative & -0.04395875 & 0.230942611 & *-0.444183563 & -0.798597321 & 0.6246531 & 6.934178 \\
\hline 6. Adaptive & 0.02365057 & -0.100878370 & -0.141358733 & 1.174631827 & 0.1829410 & 0.559755 \\
\hline Difference & -0.06760933 & 0.331820981 & -0.302824830 & -1.973229148 & & \\
\hline \multicolumn{7}{|l|}{ HR practices } \\
\hline 7. Manipulative & 0.03629721 & *-0.561515147 & ${ }^{*} 0.320406924$ & 1.097773952 & 0.5424940 & 4.940683 \\
\hline 8. Adaptive & *0.21654964 & -0.373992968 & -0.056598362 & 0.248584046 & 0.7385037 & 7.060367 \\
\hline Difference & -0.18025243 & -0.187522180 & 0.377005286 & 0.849189906 & & \\
\hline
\end{tabular}

Source: own

Note: *All correlations are significant at $p<0.05$. The number of observations $\mathrm{N}=54$.

According to those values models 2, 3, 5, 7, 8 could be considered as a significant, and the significance and reliability is discussed and models 1, 4, 6 are nonsignificant (Kutner et al., 2005). As can be seen, the rate of change of customers is significantly related to size under adaptive model but unrelated under manipulative model. Rate of change of suppliers is significantly related to suppliers' availability under manipulative model but unrelated under adaptive model. Smaller firms have smaller rate of change of customers both under the adaptive behavior and under the manipulative behavior. Rate of change of suppliers under the manipulative behavior is smaller for small firms and under the adaptive behavior it is smaller for bigger firms. Location practices are significantly related to suppliers' availability under manipulative model but unrelated under adaptive model. Human resource practices are significantly related to both finance and suppliers' availability under manipulative model but unrelated under adaptive model. Human resource practices are significantly related to company size under adaptive model.

According to the $F$ values and $R^{2}$ coefficients five of the eight models in the Tab. 3 are significant. $R^{2}$ coefficients for three models are small and do not have high predictable value, those models are nonsignificant. The reason for depreciatory significance of the model could be not large enough sample of input data or too much independent variable in the model. Nevertheless the lower significance, conclusions derived from the coefficients could be valuable information as it shows model variable independency.

In accordance with Stam (2007) results suggest, that entrepreneurs under adaptive behavioral model are satisfied with their location needs but they face human resource difficulties, supplier quality problems, bad finance availability and they have to search for new customers more often than under manipulative model. Location does not hold entrepreneurs back on the contrary it makes 
them to stand up against the perceived barriers and actively look for opportunities.

\section{Discussion}

Adaptive model behavior occurs when constraints are too stubborn to be managed by means of inducement, and entrepreneur may hedge against it. Entrepreneurs hedge against temporary losses, financial shocks by stockpiling, accumulation of a nest egg like excess resources. Business process is extremely vulnerable to slight hitches in the supply causing bottlenecks and delays. Adaptive behavior may reduce unpredictable problems and increases delivery reliability. Entrepreneurs are also rationing their priorities, they give priorities to their core problems to be resolved and externalize non-core problems. Manipulative model behavior infers the entrepreneurial behavior from active perspective. Entrepreneurs may not only counteract the constraints, they even make use of them. Many factors intervene between the availability of resources and their exploitation. It includes means firm uses to solve problems and overcome obstacles. The ability to manipulate or control the behavior of other firms or institutions comes from power of entrepreneur. Managers tackle actions by means of various decisions that can be proactive, sometimes drastic, depending on personal characteristics. They manipulate both internal and external environment in a variety of ways. Customers as well as suppliers are revised and changed proactively without regard to its interacting firms. Incentive decisions are made to maintain firm' autonomy. Decisions are made as unilateral actions, such as cancelling sales or purchases orders, withdrawing support or lobbying often lead to customers/suppliers switch and exchange of commitments. Strategies are used to achieve a power and may also include informal arrangements to guarantee provision of various kinds. Manipulative behavior includes joint ventures, mergers and strategic alliances. Sometimes it is for a limited purpose. Purposeful activities are sometimes risky, as each may fear that the others are taking out more than they are putting into the action. The purpose is to reduce drastically autonomy of other single firms. They are undertaken to meet severe constrains and uncertainty because of suppliers or competitors actions. Manipulative behavior includes producer boycotts and cartels, joint lobbying. Temporary coalitions are created to carry out projects no single firm could accomplish. The list of potential manipulative behavior strategies is limited only by the imagination of entrepreneurs and legal and normative sanctions. (Aldrich) It involves stronger rather than weaker encouragement strategies.

Whereas entrepreneurs under manipulative behavioral model satisfy their human resource needs successfully, finance sources are easily accessible to them, they flexibly reassess their suppliers regardless their availability. The data also support the idea that rate of change of customers is unrelated to both adaptive and manipulative models. This bores out the idea that customers' constancy is related to unpredicted conditions. It can be influenced by competition aspect, firm location, type of the economic activity, etc. As suggested by previous researchers, the appropriateness of relations mentioned above may depend on other circumstances that can be of further investigation.

Adaptive behavior comes when a firm has to accept situation and comply with it. For instance changing market conditions and rising consumer demand need variation. Trends are forcing firms to abandon mass-production systems and adopt tailor-made and smallbatch production. Firms must obey trends and be flexible in decision making and behavioral strategies. Change from rigid mass-production to flexible niche-production changes nature of goods, assures higher quality, wider product variety, zero stock production, shift from autocratic and commanding entrepreneurial behavior to participatory and motivating one, shift from centralized decision making to decentralized and more behavioral approach.

Research of regional business environment and business behavior of SME's in MoravianSilesian region divides entrepreneurs into three groups of satisfied, mid-satisfied and dissatisfied entrepreneurs (Šebestová, 2015). This shows research similarities equal to adaptive model of the presented research. On the other hand similarities equal to manipulative model of the presented research proves the pilot study examining entrepreneurial behavior of SMEs in South Moravian Region (Koráb \& Bumberová, 2013). It identifies areas of strategic development and sets variables on the character of entrepreneurial activities as 
"specific knowledge", "technical skills" and "innovations".

In selected regions of the Czech Republic (Zlin Region) and Slovakia (Zilina and Trencin Regions) the research of the business environment of small and medium-sized enterprises has been conducted. Current trends defined by authors show that important motives for starting entrepreneurship was to have a job or to gain money (Belás, Demjan, Habánik, Hudáková, \& Sipko, 2015).

In the early stages, firms are often in a vicious circle of ties and obstacles, and they persist with difficulty. Ties are very close, personal contacts are crucial. Small entrepreneurs prefer domestic relations, whereas bigger firms prefer higher quality, supra-regional relations prevail. Small entrepreneurs, almost by its nature, create smaller and less complex relations than the bigger ones (Brandes, Brechot, \& Franck, 2015).

Presented research has demonstrated that furthermore firms face intense pressure from the surrounding environment. However, this does not prevent it from being successful; meaning, the context of the enterprise does not necessarily hinder its performance. Firms facing difficulties can succeed in finding resources that can ensure their competitiveness. Thus, firms do not walk away in the face of adversity of their constraints. In fact, not only do they utilize such opportunities, but they also build up resistance to such obstacles and handicaps. At the same time, such obstacles often force firms into additional expenses, which increase their costs. This parallels the findings of Dosi and Marengo (2007).

Firms face a situation of uncertainty, there are frequent changes suppliers and frequent relations revisions. Results suggest that there is an emergence of new relations as a substitute for bad experiences and firms need to develop specific activities to meet their everyday needs (Dobbs \& Hamilton, 2007). Small firms focus on saving costs, while bigger firms focus on the quality. Firms try not to be dependent on only one supplier and they use information to imitate the competition.

In order to find new customers, entrepreneurs find opportunities such as: providing bio certificates, getting inspiration abroad, introducing an e-shop and direct-mail, penetrating into supermarket chains, extending product ranges, getting subsidies from state funds, receiving protection from insolvency and a reduction in sales through delayed payments, utilizing non-payment of employees, and getting credit.

Practices regarding human resources depend on conditions of the labor market and required skill structure. Human resources market conditions are the single most important factor. It depends on availability of a range of occupation-specific skill, including low-skilled production and sub optimally experienced workers. Human resource shortages often results from growth in business demand. Firms that face need of highly-skilled technicians and professionals, also face higher salary costs. High-technology skilled workers are often insufficient to satisfy an even larger demand, resulting in severe competition for experienced labor and wage inflation. Big firms had more labor recruitment and other human resources input problems than small firms.

Discovered behavioral patterns regarding personal characteristics of Czech entrepreneurs:

- Ambition to follow up on severed family ties.

- The will to maintain family traditions, feeling 'at home'.

- Placed importance on family ties, which play an important role and have priority in his decision making (Brandes, Brechot, \& Franck, 2015).

- The ambition to reach business excellence (managers seek this purposely).

- The need to create an anchor in his life and to achieve success in life.

- A daily contemplation, weighing, and endless struggle of his decision making.

- Determination to rescue a national brand or logo, and avoid acquisition by a foreign investor/competitor.

- The willingness to endure discomfort and to overcome obstacles.

- Ability to take responsibility and to confront fear and worries, personal bravery.

- Individual perception of a happy life.

The evidence presented in this study is in line with classical Cyert and March behavioral theory:

- Entrepreneurs lack perfect knowledge and have to search for information; thus, their actions are usually inconsistent.

- Entrepreneurs choose the satisfactory solution. They do not attempt to maximize 
profits. Reaching a certain aspiration level depends on a series of factors, most notably personal preferences and characteristics. (Schimmer \& Brauer, 2012)

- When the information required is difficult or uncomfortable to obtain, uncertainty is high; then, entrepreneurs tend to adopt mechanisms of imitation that spare them the need to anticipate the distant future.

- Bounded rationality leads to the semiautomatic process of entrepreneurial behavior, which is informed by the past and operates in the present. (Chandler et al., 2009)

- As the market condition and customers behavior keep changing extensively, entrepreneurs remain extremely flexible in order to fulfil buyers' needs.

\section{Conclusions}

In order to understand the decision-making processes at the heart of firm, this article shared the broad outcome of the empirical study and sought to define an autonomous status for decision making and behavior in Czech firms. It tackled questions about entrepreneurial behavioral in order to identify promising directions for the Behavioral Theory of the Firm (Cyert \& March, 1963) taking into account Czech specifics.

It would go beyond the scope of this paper to show each decision and entrepreneurial behavior strategy mentioned so far. Anyway, in order to avoid distortion dictated by the brevity, this article describes corresponding links on the theory of the firm. Monitoring the prevailing phenomena in their particular statements and a perception of the volume of their statements allowed us to deduce the main characteristics of the Czech entrepreneur.

The following outcomes based on classics (Lawrence \& Lorsch, 1967; Morgan, 1992; Kameda \& Diasuke, 2002; Sener, 2012) were generated: Entrepreneurs decide to act, depending on their personal characteristics, in ways that alter their control both over the firm and the external environment. Firms respond to handicaps resulting from location. Once the incentive comes, a response is required. Information is processed, reacted to, decision is made and choices are executed.

Decision is the execution of a choice. It is made in terms of objectives from among a set of alternatives on the basis of available information (Cyert \& March, 1963). The observations of the 54 firms attempt to tackle questions about decision making under the Czech specifics. It allows us to understand the economic behavior, to examine of how firm objectives are formed, how strategies evolve, and how solutions are reached within those strategies.

Economic decision making captures the manner in which a person makes a decision within an organization (Simon, 1957; March \& Simon, 1958). Entrepreneurs create relations around themselves, ties are uneven and are the result of limited information, they can be influenced or changed.

Studying in complex entrepreneurial behavior and perceptions of problems and their influence on steps impacting the firm, it is important to be aware of the fact that this behavior may be significantly influenced by the unique individual personal characteristics of entrepreneur (Schminke et al., 2002). Control over the firm is possible and almost inevitable in order to mitigate constraints.

Outcomes are in line with much presented previous descriptive and empirical studies on entrepreneurial behavior (Cyert \& March, 1972; Brandes et al., 2015; Kao, 2013). In the research attention was focused on entrepreneur actions and counteractions. Our findings show how and why reactions and decision processes of entrepreneurs may change. During the early stages of the firm as a start-up, entrepreneurs often fall into a vicious circle of obstacles, which makes decision making extremely difficult. Behavior and decisions are impacted by family ties, and personal characteristics.

This survey confirms the previous surveys carried out by Vaessen and Wever (1993) and Santoro (2007) who conclude that small firms prefer to make decisions according to family ties and stability; bigger firms decisions are based more on the quality, image and business performance.

It must be noted that entrepreneurs cannot react to every threat or barrier they encounter. In addition, it was observed that managers often take actions too late, not rigorously enough, or otherwise react in an inadequate way. This study does not aim to depict the managers as able to resolve all the obstacles they face. The intention is just to highlight that managers need not be at the mercy of a situation as implied by classical science. In line with Chandler et al. (2009), and surprisingly, many choices of the decision can be used to mitigate the situation. 
The evidence presented in this study confirms (Gindis, 2009), that managers do not decide so much through selective, sophisticated strategies as rather through trial and imitation of competitors. As soon as they recognize errors, they simultaneously make decisions ad hoc. The sample firms and their managers frequently have to adjust their objectives in order to survive. Surprisingly objectives were reached.

Classical management theories and the bulk of relating literature presume that this happens according to a strategic plan of grand design aimed at autonomous goal achievement (Simon, 1947; 1957; Williamson, 1963). The assignment of priorities in entrepreneurial decision making is essential. Study has proved, that in fact, managers and leaders tackle the decisions by means of various manipulative measures that can be drastic, moderate, efficient, and useless depending on their personalities (Kameda \& Diasuke, 2002).

We can extend the research trend of theorists (Lawrence \& Lorsch, 1967) accentuating endogenous approach in current management sciences. Such a direction draws attention to developing behavioral techniques aimed at generating outstanding firm performance. The behavioral patterns (Witt, 2007; Schminke et al., 2002) based on the agility and innovation, and the entrepreneurs' actions and decisions, in turn affects the atmosphere at the firm and in the business environment.

Updated theories (Sener, 2012; Chandler, 2009) include phenomena like bounded rationality, satisfying, inducement/contribution balances, attention focus, uncertainty absorption and more. Bounded rationality, imitation practice, and herd instinct play out in real organizations (Kameda \& Diasuke, 2002). Research has proved that in contrast to the opinions reported in the mainstream managerial sciences, managers do not back away from obstacles; in fact, they even search for and grasp such challenges, and they build up their resistance to such to achieve success.

Simon (1957) by pioneering decision making process in economic organizations has developed theoretical basis which has something of importance to new area of economic research made by and Brännback and Carsrud (2017). Kirkley (2016) discovered behavioral patterns in situations that are meaningful to entrepreneur. As well as presented study, he uses inductive methodological approach and finds a core set of values, which are believed to be essential, namely, independence, ambition, creativity and daring. Presented entrepreneurial behavior research tests adaptive/manipulative model and coincides with Kirkley's outcomes.

Behavioral economics discipline is experiencing a boom. This is also apparent from the fact that there are three Nobel Prizewinning economists in this sphere of behavioral economics: Simon in 1978, Kahneman in 2002 and Thaler in 2017. Richard Thaler examines humanity's flaws and explains why entrepreneurs prefer freedom of choice instead of making rational economic decisions (Thaler, 2017).

Study results suggest a number of implications for further research as well as establishing entrepreneur support policy on multiple level. Growing international business environment is too turbulent and complex for an entrepreneur to compete. Public policy should reduce the uncertainty inherent in business environment in order to promote entrepreneurial activity.

\section{References}

Belás, J., Demjan, V., Habánik, J., Hudáková, M., \& Sipko, J. (2015). The business environment of small and mediumsized enterprises in selected regions of the Czech Republic and Slovakia. E\&M Ekonomie a Management, 18(1), 95-110. https://dx.doi. org/10.15240/tul/001/2015-1-008.

Bingham, C. B., \& Haleblian, J. (2012). How firms learn heuristics: Uncovering missing components of organizational learning. Strategic Entrepreneurship Journal, 6(2), 152177. https://dx.doi.org/10.1002/sej.1132.

Brandes, L., Brechot, M., \& Franck, E. (2015). Managers' external social ties at work: Blessing or curse for the firm? Journal of Economic Behavior \& Organization, 109(1), 203-216. doi.org/10.1016/j.jebo.2014.11.013.

Brännback, M., \& Carsrud, A. L. (Eds.). (2017). Revisiting the Entrepreneurial Mind. International Studies in Entrepreneurship 35. Switzerland: Springer International Publishing. https://dx.doi.org/10.1007/978-3-319-45544-0_23.

Chakravarthy, B. (1982). Adaptation: a promising metaphor for strategic management. Academy of Management Review, 7(1), 35-44. https://dx.doi.org/10.5465/AMR.1982.4285438.

Chandler, G. N., McKelvie, A., \& Davidsson, P. (2009). Asset specificity and behavioral 
uncertainty as moderators of the sales growth - Employment growth relationship in emerging ventures. Journal of Business Venturing, 24(4), 373-387. https://dx.doi.org/10.1016/j. jbusvent.2008.04.002.

Child, J. (1972). Organizational structure, environment and performance: the role of strategic choice. Sociology, 6(1), 2-22. https://dx.doi.org/10.1177/003803857200600101.

Cyert, M. R., \& March, J. G. (1972). A behavioral theory of the firm. Malden, MA: Blackwell Publishing. https://dx.doi. org/10.2307/1884852.

Dobbs, M., \& Hamilton, R. T. (2007). Small business growth: recent evidence and new directions. International JournalofEntrepreneurial Behavior \& Research, 13(5), 296-322. https:// doi.org/10.1108/13552550710780885.

Dosi, G., \& Marengo, L. (2007). On the Evolutionary and Behavioral Theories of Organizations: A Tentative Roadmap. Organization Science, 18(3), 491-502. https:// doi.org/10.1287/orsc.1070.0279.

Field, A. J. (2007). Beyond Foraging: Behavioral Science and the Future of Institutional Economics. Journal of Institutional Economics, 3(3), 265-291. https://doi. org/10.1017/S1744137407000720.

Gindis, D. (2009). From Fictions and Aggregates to Real Entities in the Theory of the Firm. Journal of Institutional Economics, 5(1), 25-46. https://doi.org/1010.1017/S1744137408001203.

Hendl, J. (2005). Kvalitativní výzkum. Praha: Portál.

Kahneman, D. (2003). Maps of Bounded Rationality: Psychology for Behavioral Economics. American Economic Review, 93(5), 1449-1475. https://dx.doi.org/10.1257/000282803322655392.

Kameda, T., \& Diasuke, N. (2002). Costbenefit Analysis of Social/Cultural Learning in a Nonstationary Uncertain Environment: An Evolutionary Simulation and an Experiment with Human Subjects. Evolution and Human Behavior, 23(5), 373-393. https://dx.doi. org/10.1016/S1090-5138(02)00101-0.

Kao, R. W. Y. (2013). Entrepreneurial Decision making Behaviour Compared with Corporate Managers in Business Management. Journal of Small Business \& Entrepreneurship, 4(3), 12-21. doi.org/10.1080/08276331.1987. 10600266.

Keynes, J. M. (1936). The General Theory of Employment, Interest and Money. London: Palgrave Macmillan.
Kirkley, W. W. (2016). Entrepreneurial behaviour: the role of values. International Journal of Entrepreneurial Behavior \& Research, 22(3), 290-328. https://dx.doi. org/10.1108/IJEBR-02-2015-0042.

Kirzner, I. M. (1997). Entrepreneurial Discovery and the Competitive Market Process: an Austrian Approach. Journal of Economic Literature, 35(1), 60-85.

Koráb, V., \& Bumberová, V. (2013). Empirical development taxanomy of micro, small and medium-sized enterprises in South Moravian Region. Acta Universitatis Agriculturae et Silviculturae Mendelianae Brunensis, 61(7), 2021-2031. https://dx.doi. org/10.11118/actaun201361072021.

Krueger, N. F. (2007). What lies beneath? The experimental essence of entrepreneurial thinking. Entrepreneurship Theory and Practice, 31(2), 123-139. https://dx.doi.org/10.1111/ j.1540-6520.2007.00166.x.

Kutner, M. H., Nachtsheim, C., Neter, J., \& Li, W. (2005). Applied Linear Statistical Models. Boston: McGraw-Hill Irwin.

Lawrence, P. R., \& Lorsch, J. W. (1967). Organization and environment. Boston: Graduate School of Busines Administration, Harvard University.

Lucas, R. E. (1987). Models of Business cycles. Oxford: Blackwell.

March, J. G., \& Simon, H. A. (1958). Organizations. New York: Wiley.

McDermott, P., \& Taylor, M. (1982). Industrial Organisation and Location. Cambridge: Cambridge University Press.

Morgan, G. (1988). Riding the waves of change: developing managerial competence for a turbulent world. San Francisco: JosseyBass Publishers.

Morgan, G. (1992). Proactive management. In D. Mercerer (Ed.), Managing the external environment: a strategic perspective. London: Sage.

Neter, J., Wasserman, W., \& Kutner, M. H. (1985). Applied linear statistical models: regression, analysis of variance, and experimental designs. Illinois: Homewood Press.

Pred, A. R. (1967). Behavior and location: foundations for a geographic and dynamic location theory. Lund: The Royal University of Lund.

Rao, C. R. (1973). Criteria and Methods of Estimation. In Linear Statistical Inference and 
its Applications: Second Edition. Hoboken, $\mathrm{NJ}$ : John Wiley \& Sons. https://dx.doi. org/10.1002/9780470316436.ch5.

Santoro, M. D., Bierly, P. E., Daly, P. S., \& Gopalakrishnan, S. (2007). Sources of external organisational learning in small manufacturing firms. International Journal of Technology Management, 38(1-2), 45-68. https://dx.doi. org/10.1504/IJTM.2007.012429.

Schimmer, M., \& Brauer, M. (2012). Firm performance and aspiration levels as determinants of a firm's strategic repositioning within strategic group structures. Strategic organization, 10(4), 406-435. https://dx.doi. org/10.1177/1476127012457983.

Schminke, M., Cropanzano, R., \& Rupp, D. E. (2002). Organization structure and fairness perceptions: The moderating effects of organizational level. Organizational Behavior and Human Decision Processes, 89(1), 881-905. https://dx.doi.org/10.1016/S07495978(02)00034-1.

Schumpeter, J. (1934). The Theory of Economic Development. Cambridge: Harvard University Press.

Šebestová, J. (2015). Regional Business Environment and Business Behaviour of SME's in Moravian-Silesian Region. In A. Kocourek (Ed.), Proceedings of the 12th International Conference Liberec Economic Forum (pp. 182191). Liberec: Technical University of Liberec.

Sener, I. (2012). Strategic Responses of Top Managers to Environmental Uncertainty. Procedia Social and Behavioral Sciences, 58, 169-177. https://dx.doi.org/10.1016/j. sbspro.2012.09.990.

Simon, H. A. (1947). Administrative behavior. New York: Theatre Press. https:// dx.doi.org/10.1111/j.1467-6486.1967.tb00569.x.

Simon, H. A. (1957). A Behavioral Model of Rational Choice. Quarterly Journal of Economics, 69(1), 99-118. https://dx.doi. org/10.2307/1884852.
Soofi, E. S., Retzer, J. J., \& Yasai-Ardekani, M. A. (2000). Framework for measuring the importance of variables with applications to management research and decision models. Decision Sciences, 31(3), 595-625. https:// dx.doi.org/10.1111/j.1540-5915.2000.tb00936.

Stam, E. (2007). Why Butterflies Don't Leave: Locational Behavior of Entrepreneurial Firms. Economic Geography, 83(1), 27-50. https://dx.doi.org/10.1111/j.1944-8287.2007. tb00332.x.

Thaler, R. H. (2017). Misbehaving: The Making of Behavioral Economics. New York: W. W. Norton \& Company.

Vaessen, P., \& Wever, E. (1993). Spatial responsiveness of small firms. Journal of Economicand Social Geography, 84(2), 119-131. https://dx.doi.org/10.1111/j.1467-9663.1993. tb00640.x.

Williamson, O. E. (1963). Managerial Discretion and Business Behavior. American Economic Review, 53(5), 1032-1057.

Witt, U. (2007). Firms as Realizations of Entrepreneurial Visions. Journal of Management Studies, 44(7), 1125-1140. https:// dx.doi.org/10.1111/j.1467-6486.2007.00731.x.

Yasai-Ardekani, M. A. (1989). Effects of Environmental Scarcity and Munificence on the Relationship of Context to Organizational Structure. The Academy of Management Journal, 32(1), 131-156. https://dx.doi. org/10.2307/256423.

Ing. Ivana Mandysová, Ph.D. University of Pardubice Faculty of Economics and Administration Institute of Administrative and Social Sciences Czech Republic Ivana.mandysova@upce.cz 


\section{Abstract}

\section{A BEHAVIORAL THEORY OF THE FIRM: SPECIFICS OF CZECH ENTREPRENEURIAL BEHAVIOR}

\section{Ivana Mandysová}

The article attempts to present empirically relevant, process-oriented behavioral theory of the firm incorporating Czech specific characteristics of entrepreneurial behavior. It conceptually reconciles the reality by looking at the original ideas of 'A Behavioral Theory of the Firm' by Cyert and March. Study critically examines available theoretical models of firm's rational behavior investigated in heuristic theories. These models offer an interpretation of entrepreneurial behavior as a product of personal preferences and characteristics. A theoretical re-orientation towards recognition of entrepreneurial behavior is developed and illustrated. Contemporary research outcomes coincide that the emerging, probably eclectic, paradigm strongly emphasizes the role and quality of human capital including the entrepreneur's skills. Study is based on in-depth qualitative empirical research and subsequently it derives from statistically established theoretical patterns. It explores and explains the way entrepreneurs make economic decisions, their actions and counteractions with business environment, while, at the same time, focusing on Czech specifics. Firms have proved exceptional flexibility and have succeeded in counteracting and even manipulating the shortcomings and disadvantages of business environment. They have exploited chances and grasp opportunities in spite of additional expenditures that increased their costs. It has been proved that decisions are not made according to designed strategic plans aimed at the achievement of goals and permanent profit increase. Research has discovered that behavioral patterns further offer an access to specialized inputs, discovered relations proved to provide the entrepreneur with access to knowledge and information, even though bounded rationality and imperfect knowledge often lead to satisfactory solution and are typical for Czech firms. To create a dynamic economy, which ensures that entrepreneurs can start and develop their businesses, public policy should understand entrepreneurship, support it, provide relevant public goods and motivate it properly.

Key Words: Behavioral theory of the firm, entrepreneur; decision making, Czech business environment specifics.

JEL Classification: D21, D22.

DOI: 10.15240/tul/001/2018-1-006 